\title{
Dihydrosanguinarine Enhances Glucose Uptake in Mouse 3T3-L1 Cells
}

AUTHOR(S):

Chow, Yit-Lai; Iwata, Yuko; Sato, Fumihiko

CITATION:

Chow, Yit-Lai ...[et al]. Dihydrosanguinarine Enhances Glucose Uptake in Mouse 3T3-L1 Cells. ACS Omega 2017, 2(10): 6916-6925

\section{ISSUE DATE:}

2017-10-31

URL:

http://hdl.handle.net/2433/227717

\section{RIGHT:}

(C) 2017 American Chemical Society. This is an open access article published under an ACS AuthorChoice License, which permits copying and redistribution of the article or any adaptations for non-commercial purposes. 


\title{
Dihydrosanguinarine Enhances Glucose Uptake in Mouse 3T3-L1 Cells
}

\author{
Yit-Lai Chow, *(i) Yuko Iwata, and Fumihiko Sato* \\ Division of Integrated Life Science, Graduate School of Biostudies, Kyoto University, Main Building of Faculty of Agriculture, Room \\ N252, Kitashirakawa, Sakyo, Kyoto 606-8502, Japan
}

\section{Supporting Information}

ABSTRACT: Recently, more studies have aimed at identifying selective peroxisome proliferator-activated receptor gamma $(\operatorname{PPAR} \gamma)$ modulators that transactivate the expression of PPAR $\gamma$-dependent genes as partial agonists to improve diabetic symptoms with fewer side effects compared to classic PPAR $\gamma$ agonists such as thiazolidinediones. We found that dihydrosanguinarine (DHS) treatment induced preadipocyte differentiation and lipid droplet accumulation in 3T3-L1 cells, but this effect is weaker than that elicited by the full PPAR $\gamma$ agonist troglitazone. Furthermore, this effect was reduced by the addition of a PPAR $\gamma$ antagonist, indicating the involvement of $\operatorname{PPAR} \gamma$ signaling. Our results suggest that the stimulatory

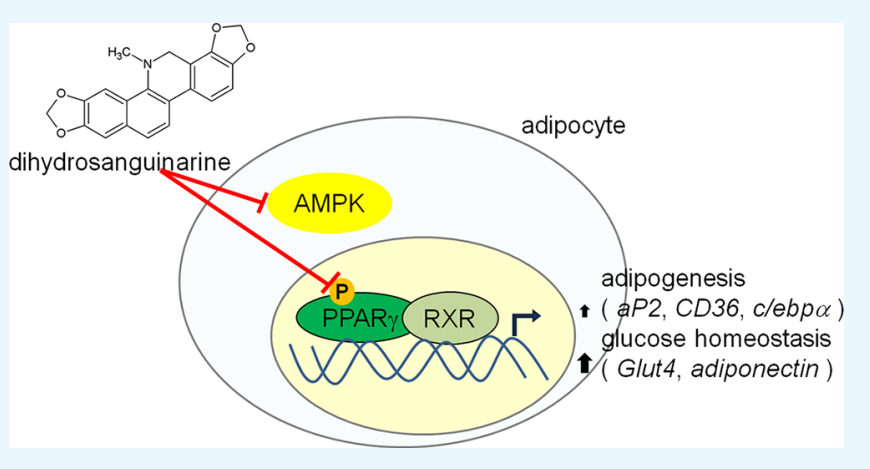
effects of DHS on adipocyte differentiation and insulin sensitivity are mediated by suppressing adenosine monophosphateactivated protein kinase (AMPK) alpha, upregulating the expression of PPAR $\gamma$ and its target genes (particularly Glut-4 and adiponectin) and reducing PPAR $\gamma$ phosphorylation. DHS significantly enhanced the glucose uptake in 3T3-L1 adipocytes without observable cytotoxicity at the effective concentration $(5 \mu \mathrm{M})$ applied.

\section{INTRODUCTION}

The adipocyte differentiation process is tightly controlled by molecular and cellular mechanisms, including transcriptional factors and extracellular proteins. Many of the genes associated with the differentiation and maintenance of the adipocyte phenotype could be involved in metabolic disorders, such as type-2 diabetes and obesity. ${ }^{1}$ Peroxisome proliferator-activated receptor gamma $(\operatorname{PPAR} \gamma)$ is a member of the nuclear receptor superfamily of ligand-inducible transcription factors and is a master regulator of adipocyte differentiation and metabolism, controlling the gene networks involved in lipid metabolism and glucose homeostasis. ${ }^{2,3}$ PPAR $\gamma$ is the ultimate effector of adipogenesis in a transcriptional cascade that also involves members of the C/EBP (CCAAT enhancer binding protein) transcription factor family. ${ }^{4,5}$ Together, these proteins regulate downstream target genes involved in adipogenesis. ${ }^{6}$ Inhibition of PPAR $\gamma$ activity was reported to exert antiadipogenic effects, and PPAR $\gamma$ antagonists have been suggested as candidate drugs for antiobesity. ${ }^{7,8}$ By contrast, hyperactivation of PPAR $\gamma$ induced adipose tissue expansion, weight gain, and fatty livers in human subjects and animals studies as well as adipogenesis in vitro., ${ }^{2,9}$ However, activation of PPAR $\gamma$ also yields beneficial effects-it has been shown to improve glucose homeostasis and insulin sensitivity. ${ }^{10,11}$ Full PPAR $\gamma$ agonists such as thiazolidinediones are an effective class of drugs for treating type-2 diabetes. However, they have serious side effects such as weight gain, bone loss, fluid retention, and cardiac risks, which has led to their restricted use in patients. ${ }^{12}$
Recently, more studies have focused on finding novel ligands-selective PPAR $\gamma$ modulators-from synthetic and natural compounds that exhibit partial agonism based on selective receptor-cofactor interactions and can target gene regulation. In vivo studies reported that some PPAR $\gamma$ activators from natural compounds, such as honokiol, amorfrutin 1, and amorphastilbol, improved metabolic parameters in diabetic animal models with fewer side effects than full PPAR $\gamma$ agonists such as thiazolidinediones. ${ }^{13}$ Many plant alkaloids were reported to possess potent pharmacological activities and have been implemented in traditional medicine as well as considered a model for modern drug synthesis. However, most of these natural products, especially the benzylisoquinoline alkaloids (BIAs), remain largely unexplored regarding their partial PPAR $\gamma$ agonistic activity. Sanguinarine is a benzophenanthridine alkaloid present in the Papaveraceae, Fumariaceae, and Rutaceae families of plants with reported antimicrobial, antiinflammatory, and antitumor activities. ${ }^{14-16}$ The pharmacokinetic results of sanguinarine in animal studies demonstrated that its in vivo availability is apparently low and that the main sanguinarine metabolic pathway is iminium bond reduction, which results in dihydrosanguinarine (DHS) formation. ${ }^{17}$ Previously, we found that BIAs exhibited lipid metabolismmodulating activity in Caenorhabditis elegans. Treatment with

Received: August 4, 2017

Accepted: October 5, 2017

Published: October 19, 2017 
(a)<smiles>CN1Cc2c(ccc3c2OCO3)-c2ccc3cc4c(cc3c21)OCO4</smiles>

Dihydrosanguinarine<smiles></smiles>

Sanguinarine (b)

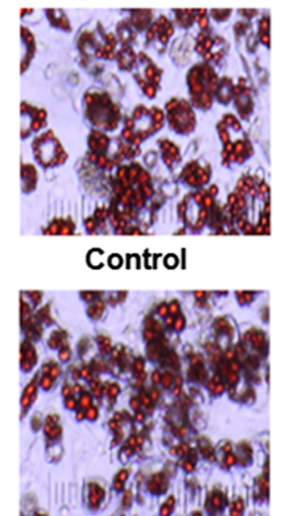

Sanguinarine $5 \mu \mathrm{M}$
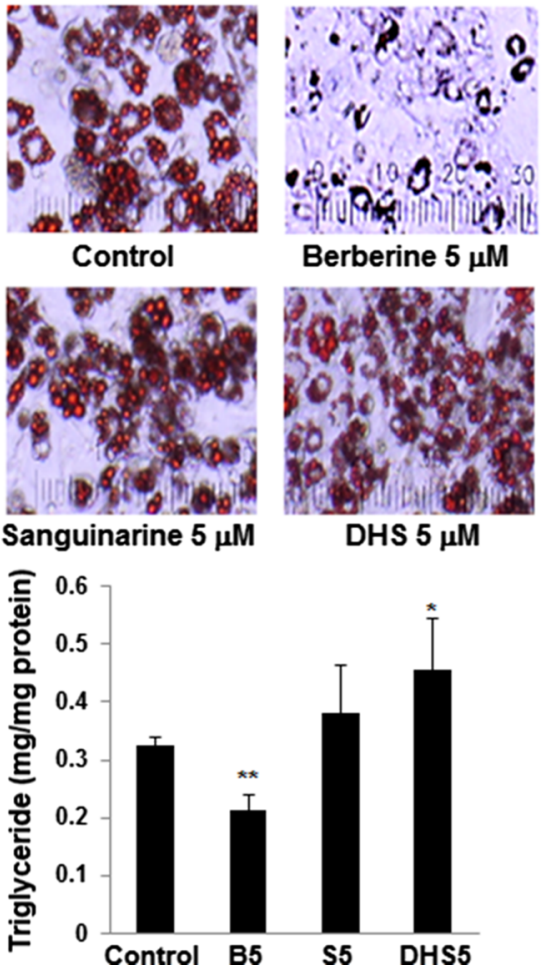

(c)

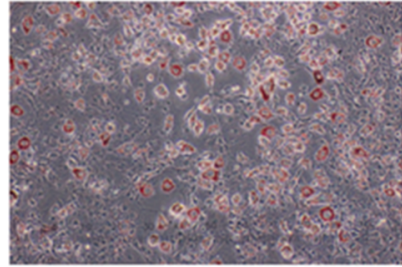

Control

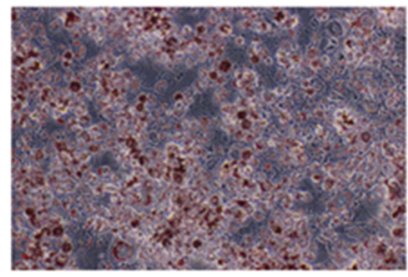

Troglitazone $5 \mu \mathrm{M}$

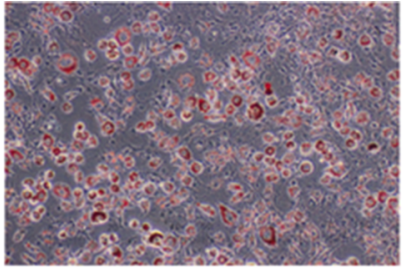

DHS $5 \mu \mathrm{M}$

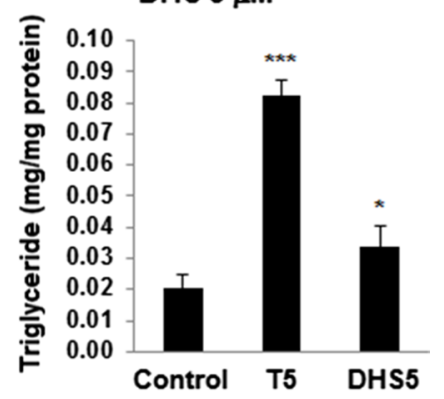

(d)

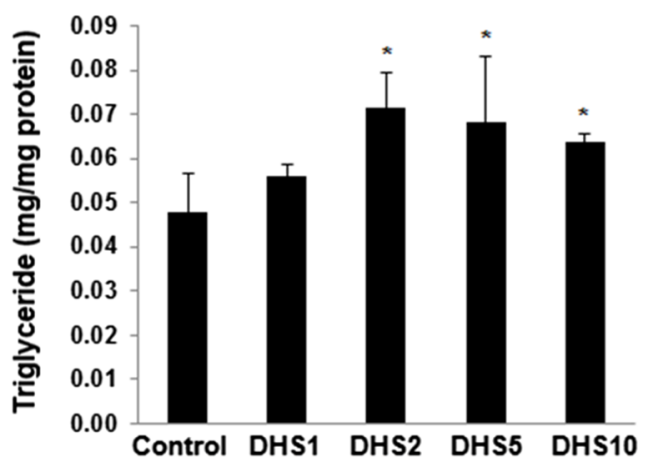

Figure 1. (a) Molecular structures of dihydrosanguinarine (DHS) and sanguinarine. (b) Oil Red O stain of 3T3-L1 adipocytes and the triglyceride content in 3T3-L1 adipocytes at day 12 and (c) day 8. All compounds were tested at $5 \mu \mathrm{M}$ [containing $0.1 \%$ dimethyl sulfoxide (DMSO)]. $n=9$ from three independent experiments. (d) Triglyceride content in 3T3-L1 adipocytes at day 8 after treatment with various concentrations of DHS. $n$ $=3$; error bar $=$ standard deviation $(\mathrm{SD}) .{ }^{*} p<0.05, * * p<0.005, * * * p 0.001$ vs control; two-tailed Student's $t$-test.

berberine and sanguinarine reduced lipid droplet accumulation in the worms. This lipid reduction effect was linked to adenosine monophosphate-activated protein kinase (AMPK) activation. ${ }^{18}$ AMPK signaling lies upstream of the PPAR $\gamma$ pathway, and AMPK activation can inhibit adipocyte differentiation and modulate energy metabolism-related gene transcription. ${ }^{19,20}$

Owing to its potential to differentiate from fibroblasts to adipocytes, the 3T3-L1 cell line has been extensively used to study adipogenesis and the biochemistry of adipocytes. ${ }^{21}$ Here, we investigated the adipogenic effect of several BIAs (DHS, sanguinarine, and berberine) in mouse 3T3-L1 adipocytes. Quantitative real-time polymerase chain reaction (RT-PCR) results showed increase of the PPAR $\gamma$ downstream target gene expressions and adipogenesis markers after DHS treatment. However, its induction of PPAR $\gamma$ was not as strong as that of the full agonist, troglitazone. Therefore, we characterized the activity of DHS associated with the PPAR $\gamma$, AMPK, and insulin signaling pathways in comparison with troglitazone. Interestingly, we found that DHS induced adipocyte differentiation, whereas its oxidized form, sanguinarine, did not. We also investigated the metabolic fate and the cytotoxicity of DHS in 3T3-L1 adipocytes.

\section{RESULTS AND DISCUSSION}

In this study, we investigated the effects of berberine and sanguinarine on lipid metabolism in mammalian cells. We also examined the activity of DHS (Figure 1a) because it is the main metabolite of sanguinarine. ${ }^{17}$ Preadipocytes (day 0) were incubated in a differentiation medium in the presence or absence of $5 \mu \mathrm{M}$ alkaloid for 2 days and then replaced with a fresh medium containing insulin in the presence or absence of alkaloid every 2 days until day 8 . The adipocytes were then stained with Oil Red O. Among the treated cells, berberinetreated cells showed reduced lipid droplet accumulation (Figure $1 b)$, and DHS-treated cells showed a higher density of lipid droplets, but the sanguinarine-treated cells showed no significant change compared to untreated cells. Quantitative measurements of the cellular triglyceride levels also indicated similar results to those of the lipid droplet staining. Next, we treated preadipocytes with troglitazone (a known PPAR $\gamma$ agonist that induces adipogenesis). Both the results of Oil Red $\mathrm{O}$ staining and the triglyceride measurement showed that DHS and troglitazone treatments increased lipid droplet accumulation in 3T3-L1 cells. However, DHS exhibited a weaker effect than troglitazone at the same concentration (Figure 1c). DHS showed a dose-dependent adipogenic effect from 2 to $10 \mu \mathrm{M}$ 


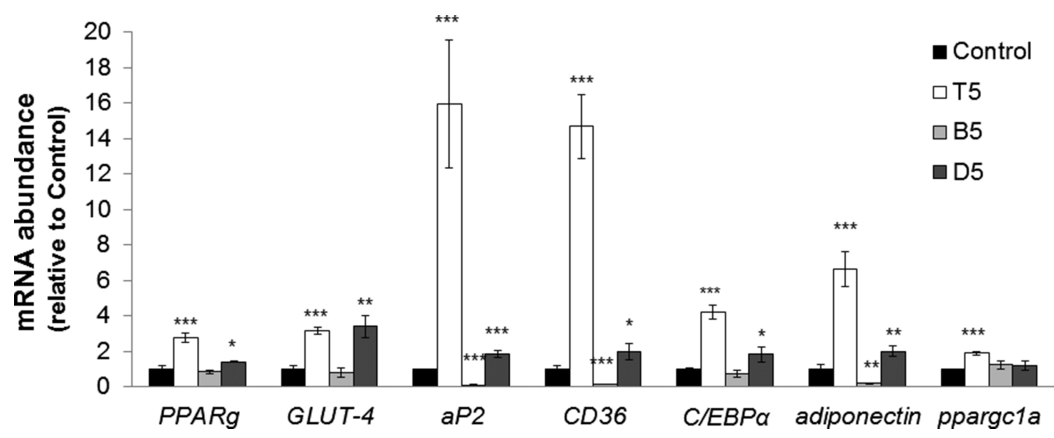

Figure 2. Quantitative RT-PCR of adipogenesis-related pathway genes. 3T3-L1 preadipocytes were treated with $5 \mu \mathrm{M}$ troglitazone (T), berberine (B), or DHS (D) for 5 days. $n=3$ from three independent experiments; error bar $=$ SD. $*_{p}<0.05, * * p<0.005$, ***p 0.001 vs control; two-tailed Student's $t$-test.

(a)

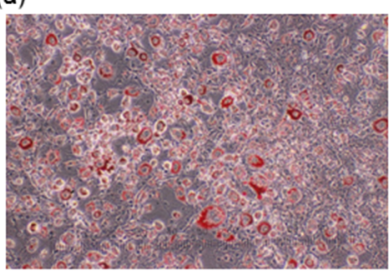

Control

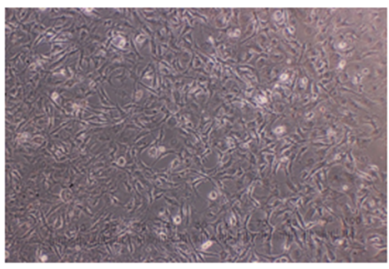

GW9662 $10 \mu \mathrm{M}$

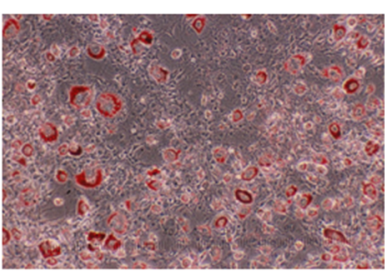

DHS $5 \mu \mathrm{M}$

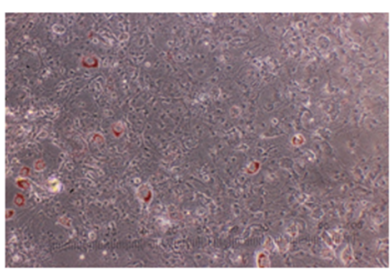

GW9662 $10 \mu \mathrm{M}+\mathrm{DHS} 5 \mu \mathrm{M}$

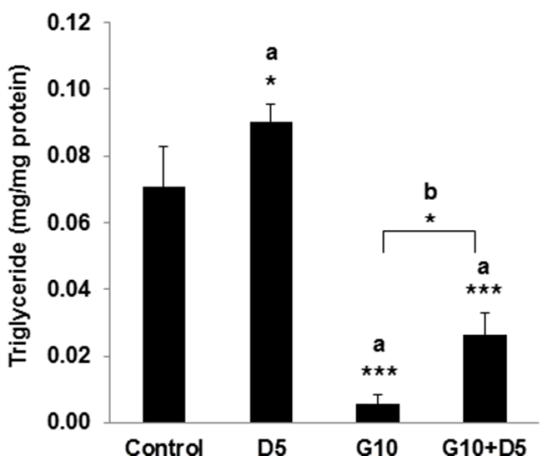

(b)

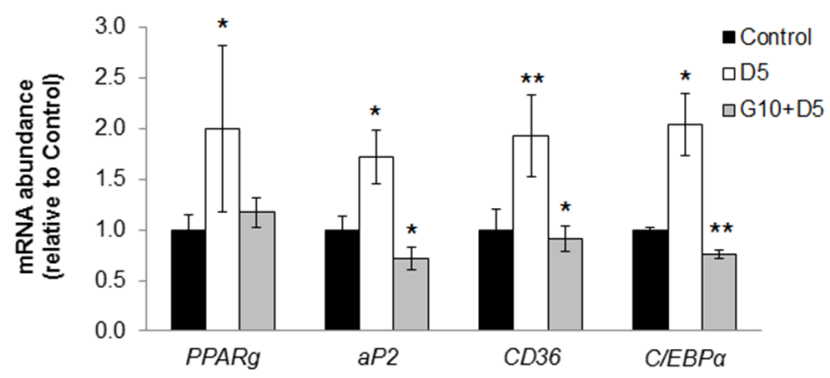

(c)
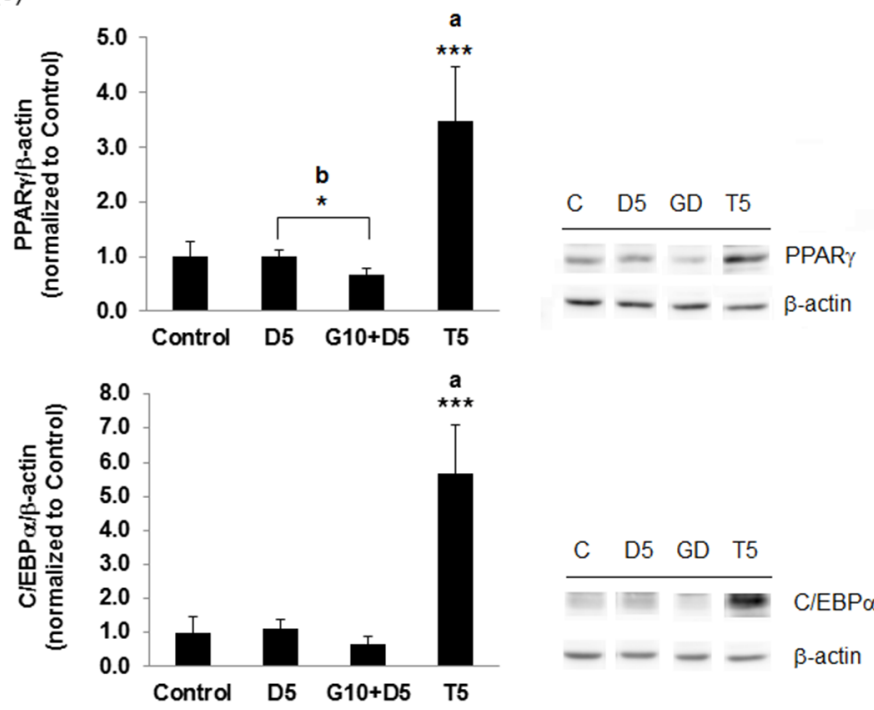

Figure 3. (a) Oil Red O staining of 3T3-L1 adipocytes and triglyceride content in 3T3-L1 adipocytes at day 8. $n=3$; error bar $=\mathrm{SD}$. $* p<0.05$, $* * * p$ $<0.001$; a-compared to control, b-compared to G10 [analysis of variance (ANOVA) followed by Dunnett's multiple comparisons test]. (b) Quantitative RT-PCR of adipogenic genes in 3T3-L1 preadipocytes treated with $5 \mu \mathrm{M}$ DHS (D5) or $10 \mu \mathrm{M}$ GW9662 and $5 \mu \mathrm{M}$ DHS (G10 + D5) for 5 days. $n=3$; error bar $=\mathrm{SD} .{ }^{*} p<0.05$, ${ }^{*} p<0.005$ compared to respective control; two-tailed Student's $t$-test. (c) Immunoblotting analyses of 3T3-L1 preadipocytes treated with $5 \mu \mathrm{M}$ DHS (D5), $10 \mu \mathrm{M}$ GW9662, and $5 \mu \mathrm{M}$ DHS (GD), or $5 \mu \mathrm{M}$ troglitazone (T5) for 5 days. $n=3$; error bar $=\mathrm{SD} . * p<0.05, * * * p<0.001$; a-compared to control, $\mathrm{b}$-compared to D5 (ANOVA followed by Dunnett's multiple comparisons test).

(Figure 1d), whereas high cytotoxicity was observed at concentrations higher than $10 \mu \mathrm{M}$ (see below).

The conversion of preadipocytes into adipocytes involves the activation of key transcription factors such as PPAR $\gamma$ and $\mathrm{C} /$ $\mathrm{EBP}$. During the differentiation process, increased $\mathrm{C} / \mathrm{EBP} \beta$ and $\mathrm{C} / \mathrm{EBP} \delta$ activity induces the transcription of $\mathrm{C} / \mathrm{EBP} \alpha$ and PPAR $\gamma .{ }^{22}$ We conducted quantitative RT-PCR to examine the effect of DHS on the expression profiles of genes involved in adipogenesis in 3T3-L1 cells compared with the effects of the same concentration $(5 \mu \mathrm{M})$ of berberine and troglitazone as well as with the nontreated control.

As shown in Figure 2, the expression of many adipogenesisrelated genes was significantly affected. The two main adipogenic transcription factors- $\mathrm{PPAR} \gamma$ and $\mathrm{C} / \mathrm{EBP} \alpha$-were significantly upregulated by troglitazone and DHS. Some PPAR $\gamma$ target genes, including adipocyte-specific genes, such as insulin-dependent glucose transporter (Glut4), adipose fatty acid-binding protein $2(a P 2)$, cluster of differentiation 36 
(a)

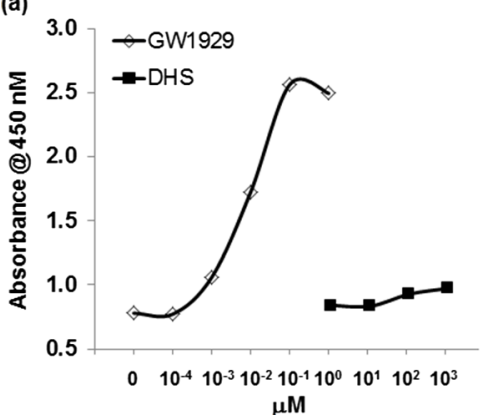

(b)

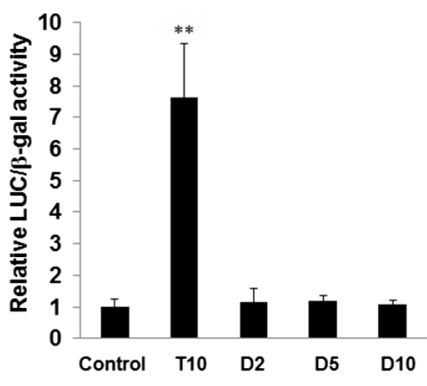

(c)

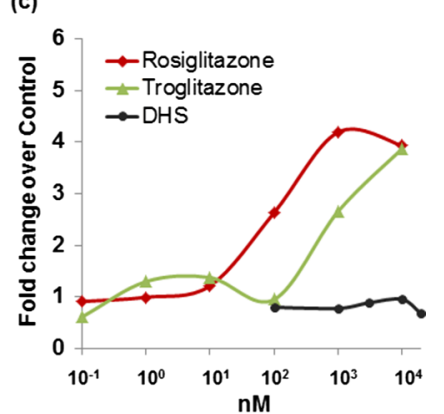

Figure 4. (a) Binding ability of DHS to PPAR in a nuclear receptor cofactor assay. GW1929 was used as a positive control. This experiment was performed in duplicate, and the average values are shown. (b) Transactivation activity of the PPAR $\gamma$-derived reporter gene in HepG2 cells after treatment with troglitazone (T) and DHS (D) in $\mu$ M. Relative luciferase activities were normalized to $\beta$-galactosidase activity. $n=3$; error bar $=$ SD. ${ }^{* *} p<0.01$ vs control, two-tailed Student's $t$-test. (c) PPAR $\gamma$ transactivation activity in 3T3-L1 cells. The average values were shown $(n=3)$. The results were normalized to control (0.1\% DMSO).

(CD36), and adiponectin, were also upregulated, suggesting that DHS enhances adipocyte differentiation through the PPAR $\gamma$ signaling pathway. Similar to the observed increases in lipid droplet accumulation (Figure 1c), DHS exhibited a weaker effect than troglitazone at a $5 \mu \mathrm{M}$ dose. By contrast, 5 $\mu \mathrm{M}$ berberine suppressed the expression of genes involved in PPAR $\gamma$ signaling as shown by the downregulated PPAR $\gamma$ target genes. These results are consistent with a report that berberine inhibits adipocyte differentiation through the PPAR $\gamma$ pathway. $^{23,24}$

PPAR $\gamma$ coactivator 1-alpha (PPARGC1A or PGC- $1 \alpha$ ) is a transcriptional coactivator for steroid receptors and nuclear receptors. It increases the transcriptional activity of $\operatorname{PPAR} \gamma$ and plays an essential role in metabolic reprogramming in response to dietary availability by coordinating the expression of a wide array of genes involved in glucose and fatty acid metabolism. ${ }^{25}$ Antidiabetic drugs such as thiazolidinediones (including troglitazone and rosiglitazone) increase insulin sensitivity by acting on the adipose, muscle, and liver to increase glucose utilization and decrease glucose production. Thiazolidinedione (rosiglitazone) treatment of obese mice boosts PGC- $1 \alpha$ transcription in the white adipose tissue, which is accompanied by increased mitochondrial function and insulin sensitivity. ${ }^{26}$ Our qRT-PCR results showed that the troglitazone treatment upregulated PPARGC1A expression in 3T3-L1 cells, whereas the effects of berberine and DHS treatment were marginal.

To investigate whether the effect of DHS is mediated by PPAR $\gamma$, we cotreated preadipocytes with DHS $(5 \mu \mathrm{M})$ and GW9662 $(10 \mu \mathrm{M})$, a PPAR $\gamma$ antagonist. Lipid droplet accumulation and triglyceride levels were significantly reduced in the presence of GW9662 compared to DHS alone (Figure 3a). However, simultaneous treatment with DHS and GW9662 did not completely eliminate the adipogenic effect of DHS on 3T3-L1 cells. This suggests the possibility of an additional mechanism involved in the adipogenic effect of DHS.

Next, we examined the impact of GW9662-mediated PPAR $\gamma$ inhibition on the upregulation of adipogenesis-related genes observed in DHS-treated cells. The qRT-PCR results showed that cotreatment of DHS with GW9662 suppressed the mRNA levels of the adipogenic factor $C / E B P \alpha$ and the target genes of PPAR $\gamma$, that is, $a P 2$ and CD36. The transcript levels of PPAR were reduced in cells treated with addition of GW9662 compared to when treated with DHS alone (Figure $3 \mathrm{~b}$ ). Furthermore, the immunoblotting results showed that the $\operatorname{PPAR} \gamma$ protein levels were significantly reduced in cells cotreated with DHS and GW9662, whereas the C/EBP $\alpha$ levels showed a trend of reduced expression (Figure 3c). These results indicate that the adipogenic effect of DHS is partially dependent on PPAR $\gamma$ signaling.

Because DHS induced adipogenesis and upregulated PPAR $\gamma$ and its downstream adipogenic marker gene expressions, we determine its potential as a ligand for PPAR $\gamma$ using a nuclear receptor cofactor assay system in comparison to GW1929, a PPAR $\gamma$ agonist which was supplied with the assay kit as the reference positive control. The half-maximal effective concentration $\left(\mathrm{EC}_{50}\right)$ values for DHS and GW1929 are approximately $30 \mu \mathrm{M}$ and $9 \mathrm{nM}$, respectively (Figure $4 \mathrm{a}$ ), whereas the reported $\mathrm{EC}_{50}$ value for troglitazone is $780 \mathrm{nM}^{27}$ This indicates that DHS has poor affinity to PPAR $\gamma$. We also carried out a $\operatorname{PPAR} \gamma$ transactivation assay to evaluate the specificity and transactivity of DHS by expressing a GAL4 DNA-binding domain/PPAR $\gamma$ ligand-binding domain (LBD) chimera protein using a pGAL4-PPAR $\gamma$ LBD plasmid and a luciferase reporter plasmid pUAS-tk-Luc containing the target sequence of GAL4 in HepG2 cells. In our luciferase reporter assay, DHS did not activate PPAR $\gamma$ in the range of $2-10 \mu \mathrm{M}$ (Figure $4 \mathrm{~b}$ ). The transactivation assay was repeated using $3 \mathrm{~T} 3-\mathrm{L} 1$ cells. Rosiglitazone and troglitazone showed PPAR $\gamma$ transactivation with $\mathrm{EC}_{50}$ values approximately 80 and $800 \mathrm{nM}$, respectively. The reported $\mathrm{EC}_{50}$ values for these full agonists using the mouse PPAR $\gamma$ receptor were $60-90$ and $780 \mathrm{nM}$, respectively, ${ }^{27}$ close to our results (Figure 4c). However, the DHS treatment showed no transactivation activity relative to the control (Figures $4 \mathrm{c}$ and S1). These results indicate that the adipogenic effect of DHS is distinct from that of full PPAR $\gamma$ agonists.

AMPK functions like biological fuel gauge, which is activated under conditions that deplete cellular adenosine triphosphate (ATP), and is phosphorylated on the catalytic $\alpha$-subunit at Thr172 by the upstream kinase LKB1. It can also be stimulated by other stimuli that do not cause a detectable change in the AMP/ATP ratio, including hyperosmotic stress and drugs such as thiazolidinediones, metformin, and 5-aminoimidazole-4carboxamide ribonucleotide. ${ }^{28}$ AMPK is activated during the lipolysis process in adipocytes and has been reported to modulate the transcription of many genes involved in energy metabolism, including lipogenesis, triglyceride synthesis, and fatty acid oxidation. ${ }^{29}$ Studies have reported that the lipidreducing effect of natural products acts via AMPK activation. These phytochemicals include polyphenols such as resveratrol, 
ginsenoside, and epigallocatechin gallate as well as plant alkaloids such as berberine and sanguinarine. ${ }^{18,30}$

AMPK $\alpha$ regulates preadipocyte differentiation by providing an upstream signal for PPAR $\gamma$ that inhibits adipocyte differentiation. ${ }^{19,20}$ We investigated the involvement of the AMPK pathway, which lies upstream of $\operatorname{PPAR} \gamma$ and $\mathrm{C} / \mathrm{EBP} \alpha$, in the adipogenic effect of DHS. The immunoblotting results showed that DHS significantly reduced the AMPK $\alpha$ levels at 5 $\mu \mathrm{M}$ but not at $10 \mu \mathrm{M}$ (Figure 5a). The effect of $5 \mu \mathrm{M}$

(a)
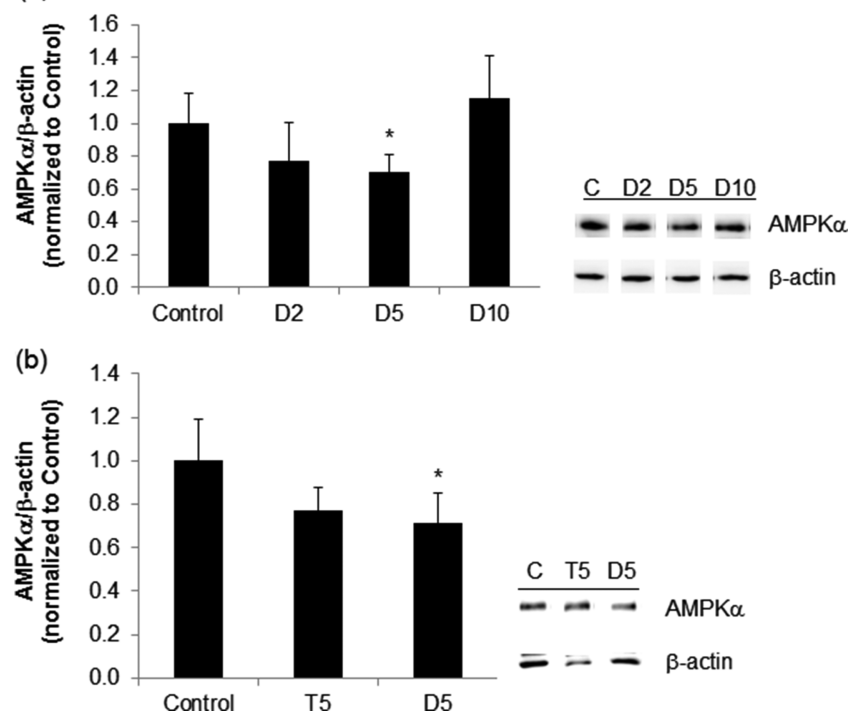

Figure 5. Immunoblotting analyses of 3T3-L1 preadipocytes treated with (a) 2 , 5, or $10 \mu \mathrm{M}$ DHS for $24 \mathrm{~h}$; (b) $5 \mu \mathrm{M}$ troglitazone or $5 \mu \mathrm{M}$ DHS for 5 days. D-DHS, T-troglitazone. $n=6$, error bar $=\mathrm{SD} . * p$ $<0.05$ vs control; two-tailed Student's $t$-test.

troglitazone on AMPK $\alpha$ levels was also insignificant (Figure $5 b)$. Although the mechanism of how certain plant natural products activate AMPK signaling while others suppress this signaling pathway is still unknown, our result implies that the DHS treatment stimulates adipocyte differentiation via upregulation of PPAR $\gamma$ by inhibiting AMPK $\alpha$-mediated signaling.

Studies have found that PPAR $\gamma$ is also regulated by posttranslational modification, resulting in insulin sensitization independent of transactivation. Phosphorylation of PPAR $\gamma$ at Ser273 by cyclin-dependent kinase 5 (CDK5) is linked to obesity. Agonists and antagonists of $\operatorname{PPAR} \gamma$ have been shown to exert their insulin-sensitizing effects by blocking CDK5/ERK phosphorylation. PPAR $\gamma$ agonists with antidiabetic effects such as thiazolidinediones were found to inhibit CDK5-mediated $\operatorname{PPAR} \gamma$ phosphorylation in the adipose tissue. ${ }^{31}$ Several PPAR $\gamma$ ligands with weak agonistic activity exhibited strong antidiabetic effects in vivo. Those ligands were shown to inhibit CDK5mediated PPAR $\gamma$ phosphorylation. As such, the ability of a ligand to suppress PPAR $\gamma$ Ser273 phosphorylation was correlated with its antidiabetic effect but independent of its agonistic activity. ${ }^{32}$ Therefore, targeted inhibition of PPAR $\gamma$ Ser273 phosphorylation was suggested for developing new classes of antidiabetic drugs.

Here, we investigated the effect of DHS on PPAR $\gamma$ Ser273 phosphorylation in comparison to troglitazone and berberine at day 5. The immunoblotting results showed that DHS increased PPAR $\gamma$ protein expression of the treated cells, but the overall
$\operatorname{PPAR} \gamma$ phosphorylation was significantly decreased (Figure 6a). The reduction of the PPAR $\gamma$ phosphorylation level by
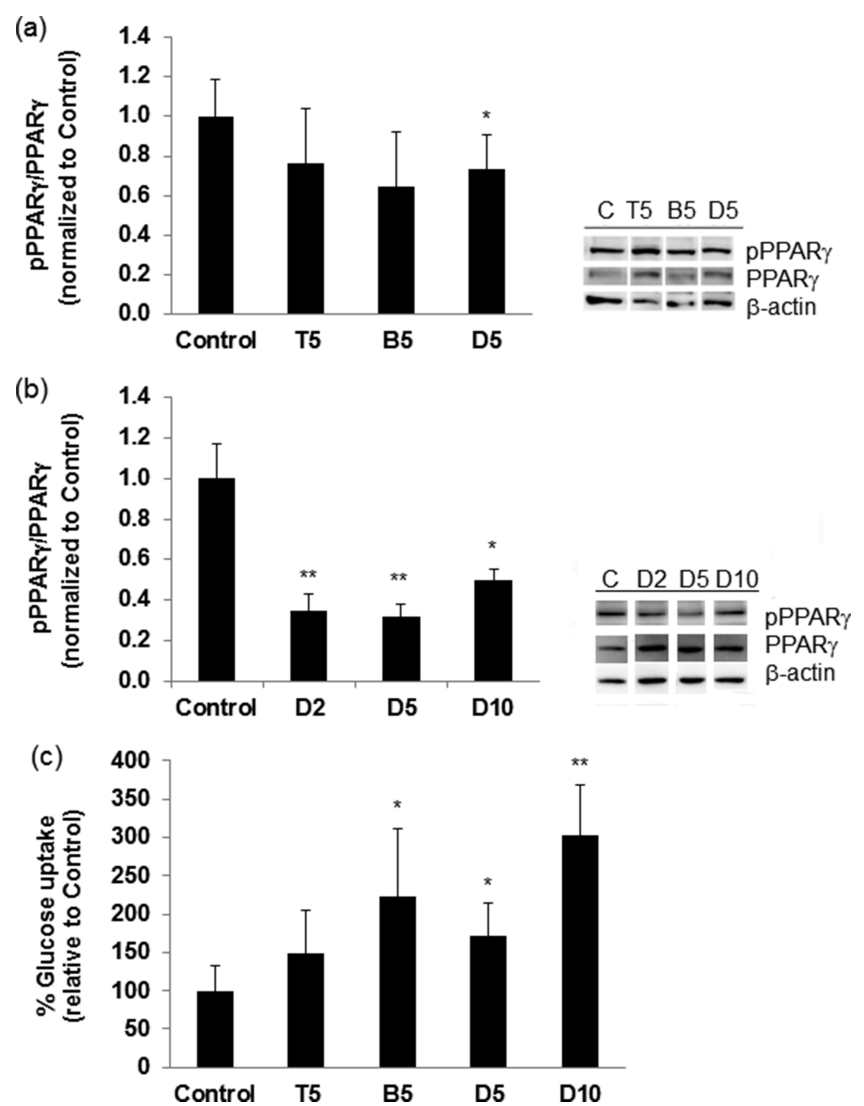

Figure 6. Immunoblotting analyses of 3T3-L1 preadipocytes treated with (a) $5 \mu \mathrm{M}$ troglitazone (T), berberine (B), or DHS (D) for 5 days. (b) 2,5 , or $10 \mu \mathrm{M}$ DHS for $24 \mathrm{~h}$. $n=3$ from three independent experiments; error bar $=\mathrm{SD} .{ }^{*} p<0.05$ vs control; two-tailed Student's $t$-test. (c) Glucose uptake effect of troglitazone (T), berberine (B), and DHS (D). Adipocytes were treated with $5 \mu \mathrm{M}$ troglitazone, $5 \mu \mathrm{M}$ berberine, or 5 or $10 \mu \mathrm{M}$ DHS. The values are normalized to the protein content of each sample. $n=3$ from three independent experiments; error bar $=\mathrm{SD} .{ }^{*} p<0.05$ vs control; two-tailed Student's $t$-test.

DHS was more apparent after $24 \mathrm{~h}$ treatment than at day 5, most possibly because of the in vivo metabolism of DHS over time. At $5 \mu \mathrm{M}$, DHS significantly reduced AMPK $\alpha$ and PPAR $\gamma$ phosphorylation levels. Treatment with $10 \mu \mathrm{M}$ DHS had no effect on AMPK $\alpha$ and showed weaker reduction of PPAR $\gamma$ phosphorylation than with $5 \mu \mathrm{M}$ DHS (Figures $6 \mathrm{~b}$ and 5a). These results suggest that DHS acts via PPAR $\gamma$ - and AMPK $\alpha$ mediated signaling, and the effects are dose-dependent. The decrease of PPAR $\gamma$ phosphorylation suggested the potential of DHS as an antidiabetic agent; therefore, we next performed a glucose uptake assay to evaluate this effect.

In the adipose tissue, PPAR $\gamma$ induces the expression of genes involved in glucose uptake and controls adipocyte-secreted factors such as adiponectin to affect whole-body insulin sensitivity. Adiponectin has been shown to play an important role in mediating glucose uptake in adipocytes and muscle cells. Recent genome-wide scans have mapped a susceptibility locus for type-2 diabetes and metabolic syndrome to chromosome $3 q 27$, where the gene-encoding adiponectin is located. ${ }^{33}$ Decreased adiponectin expression was correlated with insulin 
resistance in mouse models of altered insulin sensitivity and in type- 2 diabetes subjects. ${ }^{34}$

In mammalian cells, facilitative diffusion of glucose across the plasma membrane is mediated by a family of glucose transporters. $^{35}$ GLUT4 is a glucose transporter isoform, which is only expressed in peripheral tissues that are targets for insulin action, that is, the adipose tissue, cardiac muscle, and skeletal muscle. When stimulated by insulin, GLUT4 translocates from its intracellular compartment to the plasma membrane and, therefore, is responsible for insulin-stimulated glucose uptake. ${ }^{36}$

To evaluate whether DHS enhances glucose uptake, we used an enzymatic method to measure 2-deoxyglucose (2DG) uptake in differentiated 3T3-L1 adipocytes. Our results (Figure 6c) showed a significant stimulatory effect of insulin-dependent glucose uptake by DHS in a dose-dependent manner ( 5 and 10 $\mu \mathrm{M})$. The berberine treatment also significantly increased glucose uptake in the adipocytes, whereas the troglitazone treatment only showed a trend of increased glucose uptake. Berberine has been reported to increase glucose uptake possibly through a mechanism other than PPAR $\gamma$ activation, as this compound showed antagonistic activity. The expression and cellular localization of GLUT4 were not altered by berberine; instead, it was suggested to stimulate glucose uptake in 3T3-L1 adipocytes and preadipocytes by increasing GLUT1 activity. ${ }^{37}$ These results indicate that the effects of DHS and berberine on glucose uptake act through distinct mechanisms. Future studies should elucidate the involvement of GLUT1 and GLUT4 plant alkaloid-mediated glucose uptake. It is worth noting that while both DHS and troglitazone treatment strongly upregulated Glut-4 gene expression, induction of the proadipogenic gene adiponectin by DHS was less pronounced (Figure 2). This suggests that DHS promotes glucose uptake but exhibits weaker adipogenicity compared to troglitazone, a thiazolidinedione for treating type-2 diabetes.

In drug development, findings from many studies proposed that the ligand occupancy time on the receptor would improve the potency of PPAR $\gamma$ modulators by creating an extended period of protection against kinase activity, that is, longer residence times of a drug occupying a target result in improved duration of action times for that drug. ${ }^{38}$

Here, we investigated the metabolic fate of DHS and sanguinarine in 3T3-L1 cells by measuring their accumulation in vivo and in the culture medium after $48 \mathrm{~h}$ using both alkaloids as standards. A total of $5.7 \mu \mathrm{mol} / \mathrm{g}$ protein of DHS and $0.1 \mu \mathrm{mol} / \mathrm{g}$ protein of sanguinarine were detected in the DHS-treated cell extract, whereas $2.7 \mu \mathrm{mol} / \mathrm{g}$ protein of DHS and $0.3 \mu \mathrm{mol} / \mathrm{g}$ protein of sanguinarine were detected in the sanguinarine-treated cell extract. In the cell culture medium, 0.1 $\mu \mathrm{M}$ each of DHS and sanguinarine were detected in the DHStreated sample, whereas $0.1 \mu \mathrm{M}$ DHS and $0.3 \mu \mathrm{M}$ sanguinarine were detected in the sanguinarine-treated sample. This indicates high accumulation of DHS in both the cell extract samples, whereas sanguinarine, the oxidized form, was prevalent in the culture medium (Figure 7a). This result correlates with those reported in vivo pharmacokinetic studies that the main sanguinarine metabolism pathway is the reduction of its iminium bond to form DHS. ${ }^{16}$ It also indicates that DHS has higher accumulation in vivo than sanguinarine and may yield high bioavailability. The cells treated with $10 \mu \mathrm{M}$ DHS showed an insignificant reduction of the AMPK $\alpha$ level and weaker effects on the reduction of the PPAR $\gamma$ phosphorylation level and on adipogenesis compared to $5 \mu \mathrm{M}$ DHS. Toxicity was also

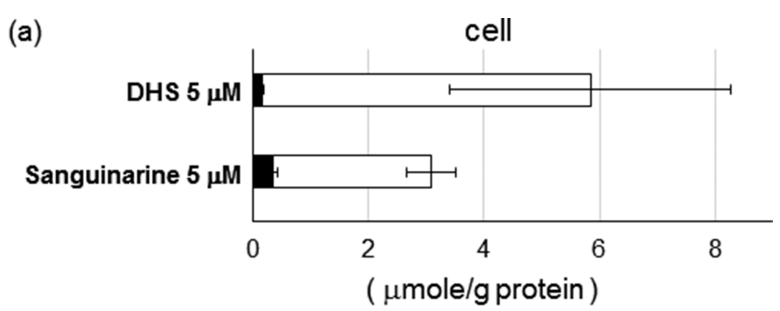

- Sanguinarine $\square$ DHS
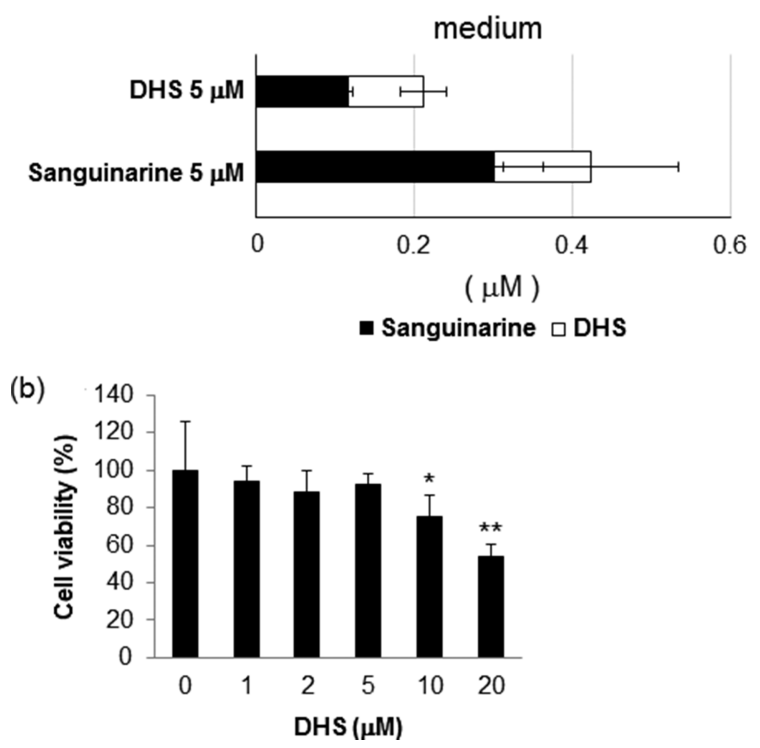

Figure 7. (a) Accumulation of DHS and sanguinarine in cells and in the cell culture medium after $48 \mathrm{~h}$ treatment with the respective compound. $n=3$ from two independent experiments; error bar $=\mathrm{SD}$. (b) 3T3-L1 adipocyte viability after $24 \mathrm{~h}$ treatment with DHS at various concentrations. $n=5$ from three independent experiments; error bar $=\mathrm{SD}$. $* p<0.05, * * p<0.005$ vs control; two-tailed Student's t-test.

observed with the $10 \mu \mathrm{M}$ treatment on the 3T3-L1 cells. These findings led us to infer that with $10 \mu \mathrm{M}$ DHS, the cells accumulated a higher amount of sanguinarine than the cells with the $5 \mu \mathrm{M}$ treatment. As described in our previous work, ${ }^{18}$ sanguinarine exerts an antiadipogenic effect, activates AMPK, and thus elicits an opposing effect to DHS.

The observed different effects of sanguinarine and DHS on the adipogenesis of 3T3-L1 cells suggest that the metabolic pathway of a bioactive compound dictates the ultimate biological effects in vivo. In our previous study, the sanguinarine treatment activated the AMPK pathway, which led to the inhibition of lipid synthesis in C. elegans. ${ }^{18}$ Although the mechanism of how sanguinarine activated AMPK signaling is still not fully elucidated, other studies suggested that this activity was due to the inhibition of mitochondrial respiratory complex I, which resulted in an increase of the AMP/ATP ratio. Sanguinarine has also been reported to activate the mitochondrial apoptosis pathway. ${ }^{39}$ We found that the sanguinarine treatment exhibited toxicity in C. elegans. ${ }^{18}$

Evaluation of 3T3-L1 cell viability showed that the cytotoxicity of DHS was insignificant at $5 \mu \mathrm{M}$ (Figure $7 \mathrm{~b}$ ). This suggests that the cytotoxicity of a compound could contribute to lipid metabolism because of its effect on AMPK pathway activation. Thus, it would be interesting to investigate the effect of bioactive compounds and their metabolites on the multiple signaling pathways involved in adipogenesis and 
glucose metabolism to elucidate their possible mechanisms of action and evaluate their potential antiobesity and/or antidiabetic effects.

In terms of differences in the molecular structure, the absence of a positive charge and the nonplanarity due to lack of conjugation in DHS was reported to be linked with decreased biological activity compared to sanguinarine. ${ }^{40}$ However, those studies only evaluated the toxicological effect of DHS such as inhibition of protein kinase $\mathrm{C}$ and cytotoxicity in cancer cells, whereby it was found that sanguinarine was more cytotoxic than DHS. For instance, in the human leukemia HL-60 cell line, the half-maximal inhibitory concentration, $\mathrm{IC}_{50}$ values of sanguinarine and DHS were reported as 0.72 and $20 \mu \mathrm{M}$, respectively. ${ }^{41}$ The in vivo toxicity of sanguinarine was reported as $2.7 \mathrm{mg} / \mathrm{kg}$ body weight in mice, whereas no toxic response was found in rats fed with DHS up to a dose of $58 \mathrm{mg} / \mathrm{kg}$ body weight per day. ${ }^{42,43}$ Our finding that DHS has low cytotoxicity makes this compound a potential candidate for therapeutic application.

\section{CONCLUSIONS}

This is the first report that evaluated the effect of DHS, a reduced form of sanguinarine, on adipogenesis in 3T3-L1 cells. DHS exhibited a weaker adipogenic effect than the full PPAR agonist, troglitazone. Our results suggest that DHS induced adipocyte differentiation by upregulating $\operatorname{PPAR} \gamma$ and suppressing AMPK signaling pathways. DHS treatment reduced PPAR $\gamma$ Ser273 phosphorylation and upregulated the expressions of Glut-4 and adiponectin genes-activities that are associated with improved insulin sensitivity. We found that $5 \mu \mathrm{M}$ DHS significantly enhanced glucose uptake in 3T3-L1 adipocytes without exerting cytotoxicity. Further experiments using animal models are needed to evaluate the efficacy and safety of DHS for medical application. Although the interaction of DHS with PPAR $\gamma$ is not fully elucidated, our results show that DHS bound weakly with $\operatorname{PPAR} \gamma$ and did not transactivate it. Crystallographic structures of the PPAR $\gamma$ ligand binding revealed two binding modes exist in the same LBD that correspond to potent and weak agonists and affect their transactivation activities. A weak agonist could have low transactivation activity but high phosphorylation inhibition activity on PPAR $\gamma$ Ser273, similar to the characteristics of DHS discovered in this study. ${ }^{44-46}$ By examining the metabolic fates of DHS and its oxidized form, sanguinarine, in 3T3-L1 cells, we discovered the significance of considering the metabolites of a compound during bioactivity screening. This is because the metabolic pathway of a bioactive compound ultimately dictates the biological effect in vivo. Our findings in this study suggest that BIAs could be potential lead compounds for modulators of glucose metabolism, and additional screening of these alkaloids should be carried out in the future.

\section{EXPERIMENTAL SECTION}

4.1. Chemicals. Berberine sulfate was purchased from Tokyo Chemical Industry Co., Ltd. (Tokyo, Japan); troglitazone and GW9662 from Wako Pure Chemical Industries, Ltd. (Osaka, Japan); and sanguinarine chloride and rosiglitazone from Sigma-Aldrich (St. Louis, MO, U.S.A.). DHS was prepared by reducing sanguinarine with $\mathrm{NaBH}_{4}$ reduction. ${ }^{47}$ The purity was analyzed by LC-MS (see below and Figure S2). Alkaloid samples are diluted in DMSO (Wako) to a final concentration of $0.1 \%$ DMSO in cell treatments. All other chemicals were purchased from Wako, unless otherwise stated.

4.2. Purity Check. The purities of dihydrosanguinarine and sanguinarine were analyzed by an LCMS2010 system (Shimadzu, Japan) using a TSK-gel ODS-80Tm $4.6 \times 250$ $\mathrm{mm}$ column. The samples were analyzed under the following conditions: a column temperature of $40^{\circ} \mathrm{C}$; a flow rate of 0.5 $\mathrm{mL} / \mathrm{min}$; and a gradient schedule of $0-15 \mathrm{~min}$ of $\mathrm{AcCN} / \mathrm{H}_{2} \mathrm{O}$ $=45: 55,18.5-24.5 \mathrm{~min}$ of $\mathrm{AcCN} / \mathrm{H}_{2} \mathrm{O}=80: 20$, and $28-33$ min $\mathrm{AcCN} / \mathrm{H}_{2} \mathrm{O}=45: 55$ (containing $1 \%$ trifluoroacetic acid) in positive SIM-SCAN mode ranging from $\mathrm{m} / z 100-500$. The purities were calculated based on $\%$ peak area for each sample.

4.3. Cell Culture. 3T3-L1 cells (a generous gift from Dr. M. Nagao, Kyoto University) were cultured at $37{ }^{\circ} \mathrm{C}, 5 \% \mathrm{CO}_{2}$ in Dulbecco's modified Eagle medium (DMEM; Wako) with $10 \%$ fetal bovine serum (FBS; Corning). Cells were passaged twice before used in assays to allow cells to re-establish the normal cell cycle. Cell differentiation was induced at 2 day postconfluence (designated as day 0) by addition of the 3isobutyl-1-methylxanthine (IBMX) mix which consists of $5 \mu \mathrm{g}$ / $\mathrm{mL}$ insulin (Sigma), $500 \mu \mathrm{M}$ isobutylmethylxanthine (Sigma), and $0.25 \mu \mathrm{M}$ dexamethasone for 2 days. $^{48}$ The culture medium was replaced every 2 days thereafter with DMEM containing $10 \%$ FBS and $5 \mu \mathrm{g} / \mathrm{mL}$ insulin.

4.4. Oil Red O Staining. 3T3-L1 adipocytes (day 8 or day 12) in the wells of cell culture plates were rinsed with phosphate-buffered saline (PBS) and then fixed in formalin for $30 \mathrm{~min}$ at room temperature. The formalin was removed, and the cells were rinsed twice with PBS. A $0.3 \mathrm{w} / \mathrm{v} \%$ Oil Red O (Sigma) solution was added at room temperature to stain the cells. After $1 \mathrm{~h}$, cells were rinsed with PBS twice, and lipid droplet accumulation was observed under a microscope.

4.5. Triglyceride and Protein Measurement. 3T3-L1 adipocytes (day 12) in the wells of cell culture plates were rinsed twice with PBS. Cell lysis buffer (1 M Tris-HCl pH7.5, 1 $\mathrm{M} \mathrm{MgCl}_{2}, 10 \%$ Triton X100) was added to each well, and the cells were harvested using a cell scraper into Eppendorf tubes. The cells were disrupted using an ultrasonicator. Triglyceride and protein contents of the cell lysates were measured. The triglyceride concentration was determined using triglyceride $\mathrm{E}$ test kit (Wako) and the absorbance at $595 \mathrm{~nm}$ was measured using a PowerScan4 plate reader (DS Pharma Biomedical, Japan). Protein concentrations were determined using Bio-Rad DC protein assay (Bio-Rad Laboratories, U.S.A.) reagents and the absorbance at $595 \mathrm{~nm}$ was measured using the PowerScan 4 plate reader. The triglyceride content of each cell sample was normalized to its corresponding protein content.

4.6. Quantitative RT-PCR. Two day postconfluent 3T3-L1 cells (day 0 ) were cultured in the differentiation medium IBMX without or with the addition of alkaloids for 2 days, followed by medium change to DMEM/10\% FBS $/ 5 \mu \mathrm{g} / \mathrm{mL}$ insulin without or with the addition of alkaloids. The cells were harvested on day 5 following the method for protein as described above. RNAs were extracted using RNeasy Mini Kit (QIAGEN). Reverse transcription was done using $2 \mu \mathrm{g}$ of total RNA, and RT-PCR was carried out using a CFX96 RT-PCR System (BioRad Laboratories, Inc., Foster City, CA, U.S.A.). The conditions for PCR reactions were $95{ }^{\circ} \mathrm{C}$ for $15 \mathrm{~min}$, followed by 40 cycles of $95{ }^{\circ} \mathrm{C}$ for $10 \mathrm{~s}, 60^{\circ} \mathrm{C}$ for $20 \mathrm{~s}$, and $72{ }^{\circ} \mathrm{C}$ for 20 s. Melting curve analysis was performed after each run at 72 $-95{ }^{\circ} \mathrm{C}$ to check the specificity of amplification. Data analysis was done using the $\Delta \Delta C T$ method, and a relative transcript amount was standardized using the TATA box-binding protein 
as the internal control. Fold changes between samples were normalized to control (0.1\% DMSO).

4.7. Immunoblot Analysis. 3T3-L1 cells were rinsed twice with PBS. Cell lysis buffer (50 mM Tris- $\mathrm{HCl} \mathrm{pH} 7.4,150 \mathrm{mM}$ $\mathrm{NaCl}, 1 \mathrm{mM}$ ethylenediaminetetraacetic acid, $1 \%$ Triton X100, $0.1 \%$ sodium dodecyl sulfate (SDS), $10 \mathrm{mM} \mathrm{NaF}, 1 \mathrm{mM}$ $\mathrm{Na}_{3} \mathrm{VO}_{4}, 50 \mathrm{mM} \mathrm{Na} \mathrm{P}_{2} \mathrm{O}_{7}$, and $1 \%$ protease inhibitor cocktail) was added to each well, and the cells were harvested using a cell scraper into Eppendorf tubes. The cells were disrupted using the ultrasonicator. Protein contents of cell lysate samples were measured as mentioned above and adjusted to the same amount using a $2 \times$ sample buffer $(0.1 \mathrm{M}$ Tris- $\mathrm{HCl} \mathrm{pH} 6.8,2 \%$ SDS, $12 \% \beta$-mercaptoethanol, $20 \%$ glycerol, and $0.2 \%$ bromophenol blue). The protein $(20 \mu \mathrm{g})$ was loaded and separated by SDS-polyacrylamide gel electrophoresis. The proteins were electro-transferred onto a polyvinylidene difluoride membrane (Millipore Immobilon-P). The membranes were blocked for $1 \mathrm{~h}$ at room temperature in $5 \%$ bovine serum albumin (BSA)/Tris buffered saline with Tween-20 (TBST) and then probed with primary antibody (in 5\% BSA/ TBST) overnight at $4{ }^{\circ} \mathrm{C}$, followed by horseradish peroxide (HRP)-conjugated secondary donkey antirabbit IgG (in 5\% BSA/TBST). Target-specific antibodies were obtained from the following manufacturers: $\operatorname{AMPK} \alpha, \mathrm{C} / \operatorname{EBP} \alpha, \operatorname{PPAR} \gamma$, and $\beta$ actin from Cell Signaling Technology (Beverly, MA, U.S.A.); phosphospecific PPAR $\gamma$ (Ser273) from Funakoshi Co., Ltd. (Japan); and HRP-conjugated donkey antirabbit IgG from GE Healthcare (Buckinghamshire, U.K.). Chemiluminescence was detected using a ChemiDoc Touch imaging system (Bio-Rad Laboratories, Inc., U.S.A.). The blots were then stripped and reprobed with other primary antibodies and subjected to chemiluminescence detection. The target protein band intensity was quantified using ImageJ software (NIH). The average values were normalized to control.

4.8. PPAR $\gamma$ Binding Assay. The ability of DHS to bind $\operatorname{PPAR} \gamma$ was determined using the EnBio receptor cofactor assay system for PPAR $\gamma$ Kit (EnBio Tec. Laboratories Co., Ltd., Tokyo, Japan) following the manufacturer's protocol. This system employs a cell-free assay using nuclear receptors and cofactors to screen for chemicals. Changes in the absorbance at $450 \mathrm{~nm}$ for reactions treated with DHS, and the $\operatorname{PPAR} \gamma$ agonist GW1929 (positive control) were measured using the PowerScan 4 plate reader. The $\mathrm{EC}_{50}$ values were determined from the concentration that elicited a half-maximal response concentration on the plotted graphs.

4.9. PPAR $\gamma$ Reporter Assay. The assay was performed as previously described. ${ }^{49}$ A DNA fragment encoding the LBD (residues 204-505) of mouse PPAR 2 (GenBank U09138) with BamHI and SalI sites at the ends was amplified by PCR using genomic DNA from mouse 3T3-L1 cells as a template and inserted into the pSG424 plasmid at the BamHI and SalI sites to construct pGal4-PPAR $\gamma$ LBD. pGal4-PPAR $\gamma$ LBD and pUAS-tk-luc were cotransfected into HepG2 or 3T3-L1 cells in separate experiments using HilyMax (Dojindo). The PPAR $\gamma$ agonist activity was determined via luciferase activity using a Luciferase Assay System according to the manufacturer's protocol (Promega). The $\beta$-galactosidase activity was determined using chlorophenol red- $\beta$-D-galactopyranoside (Roche). Relative luciferase activities were normalized to the $\beta$ galactosidase activity.

4.10. Glucose Uptake Assay. The assay was performed according to the reported method ${ }^{50}$ with modifications. The 3T3-L1 cells were differentiated in six-well culture plates. Test compounds were added to differentiated adipocytes on day 8 . Insulin stimulation and glucose uptake were conducted on day 12. Cells were lysed with $10 \mathrm{mM}$ Tris- $\mathrm{HCl}$ buffer $(\mathrm{pH} \mathrm{8.0)}$ and disrupted using the ultrasonicator. Glucose uptake was determined by 2-deoxyglucose uptake with an enzymatic photometric assay using 2-deoxyglucose uptake measurement kit (Cosmo Bio Co., Ltd., Japan). Measurements were done using the PowerScan 4 plate reader at an absorbance of $420 \mathrm{~nm}$ in a kinetic program with a read every $1 \mathrm{~min}$ for $30 \mathrm{~min}$. Glucose uptake values were then normalized to the protein value of the cell lysates as determined by the Bio-Rad DC Protein Assay method described above. The insulin-induced glucose uptake was calculated by subtracting the values from the negative control (glucose uptake inhibitor added).

4.11. Alkaloid Accumulation Analysis. 3T3-L1 adipocytes (day 4) were treated without or with alkaloids for $48 \mathrm{~h}$ and collected as in protein samples. Cell lysis samples and cell culture media were extracted with methanol using Sep Pak C18 cartridges (Millipore). Methanol extracts were concentrated using a rotary evaporator. The samples were analyzed using an LCMS2020 system (Shimadzu) according to the previously reported method. ${ }^{23}$ Alkaloid concentrations were calculated based on the LC peak area relative to the standard peak area, and those values are normalized to the protein content in each sample.

4.12. Cytotoxicity Assay. The $3 \mathrm{~T} 3-\mathrm{L} 1$ cells were cultured at a density of $1.5 \times 10^{3}$ cells/well in a 96-well plate for $16 \mathrm{~h}$. The culture medium was then replaced with a fresh medium with the addition of alkaloids and further cultured for $24 \mathrm{~h}$. Cell viability was determined using Cell Counting Kit-8 (Dojindo). Cells were incubated with the reagent for $2 \mathrm{~h}$ and live cells were measured using the PowerScan 4 plate reader at an absorbance of $450 \mathrm{~nm}$.

\section{ASSOCIATED CONTENT}

\section{S Supporting Information}

The Supporting Information is available free of charge on the ACS Publications website at DOI: 10.1021/acsomega.7b01134.

Reporter assay showing the transactivation activity of the PPAR $\gamma$-derived reporter gene in 3T3-L1 cells after treatment with DHS (Figure S1); LC chromatogram showing the UV absorbance at $280 \mathrm{~nm}$; and the mass spectra of dihydrosanguinarine and sanguinarine (Figure S2) (PDF)

\section{AUTHOR INFORMATION}

\section{Corresponding Authors}

*E-mail: yitlaichow@yahoo.com (Y.-L.C.).

*E-mail: fsato@lif.kyoto-u.ac.jp (F.S.).

ORCID

Yit-Lai Chow: 0000-0003-3747-7366

\section{Author Contributions}

Y.-L.C. and F.S. designed the study. Y.-L.C. and Y.I. performed the experiments. Y.-L.C., Y.I., and F.S. analyzed the data. Y.L.C. and F.S. wrote the manuscript. All authors reviewed the results and approved the final version of the manuscript.

\section{Funding}

This research was supported by Grant-in-Aid for Scientific Research (S) (26221201 to F.S.).

\section{Notes}

The authors declare no competing financial interest. 


\section{ACKNOWLEDGMENTS}

We thank Dr. Masaya Nagao for generously providing the 3T3L1 cells and guidance on the cell culture system.

\section{REFERENCES}

(1) Jessen, B. A.; Stevens, G. J. Expression profiling during adipocyte differentiation of 3T3-L1 fibroblasts. Gene 2002, 299, 95-100.

(2) Evans, R. M.; Barish, G. D.; Wang, Y.-X. PPARs and the complex journey to obesity. Nat. Med. 2004, 4, 355-361.

(3) Tontonoz, P.; Spiegelman, B. M. Fat and beyond: the diverse biology of PPAR $\gamma$. Annu. Rev. Biochem. 2008, 77, 289-312.

(4) Wu, Z.; Rosen, E. D.; Brun, R.; Hauser, S.; Adelmant, G.; Troy, A. E.; McKeon, C.; Darlington, G. J.; Spiegelman, B. M. Crossregulation of $\mathrm{C} / \mathrm{EBP} \alpha$ and $\operatorname{PPAR} \gamma$ controls the transcriptional pathway of adipogenesis and insulin sensitivity. Mol. Cell 1999, 3, 151-158.

(5) Rosen, E. D.; Hsu, C.-H.; Wang, X.; Sakai, S.; Freeman, M. W.; Gonzalez, F. J.; Spiegelman, B. M. C/EBP $\alpha$ induces adipogenesis through PPAR $\gamma$ : a unified pathway. Genes Dev. 2002, 16, 22-26.

(6) Semsarian, C.; Wu, M. J.; Ju, Y. K.; Marciniec, T.; Yeoh, T.; Allen, D. G.; Harvey, R. P.; Graham, R. M. Skeletal muscle hypertrophy is mediated by a $\mathrm{Ca}^{2+}$-dependent calcineurin signaling pathway. Nature 1999, 400, 576-581.

(7) Choi, J. S.; Kim, J.-H.; Ali, M. Y.; Min, B.-S.; Kim, G.-D.; Jung, H. A. Coptis chinensis alkaloids exert anti-adipogenic activity on 3T3-L1 adipocytes by downregulating C/EBP- $\alpha$ and PPAR- $\gamma$. Fitoterapia 2014, 98, 199-208.

(8) Zhang, Y.; Yu, L.; Cai, W.; Fan, S.; Feng, L.; Ji, G.; Huang, C. Protopanaxatriol, a novel PPAR $\gamma$ antagonist from Panax ginseng, alleviates steatosis in mice. Sci. Rep. 2014, 4, 7375.

(9) Kubota, N.; Terauchi, Y.; Miki, H.; Tamemoto, H.; Yamauchi, T.; Komeda, K.; Satoh, S.; Nakano, R.; Ishii, C.; Sugiyama, T.; Eto, K.; Tsubamoto, Y.; Okuno, A.; Murakami, K.; Sekihara, H.; Hasegawa, G.; Naito, M.; Toyoshima, Y.; Tanaka, S.; Shiota, K.; Kitamura, T.; Fujita, T.; Ezaki, O.; Aizawa, S.; Nagai, R.; Tobe, K.; Kimura, S.; Kadowaki, T. PPAR gamma mediates high-fat diet-induced adipocyte hypertrophy and insulin resistance. Mol. Cell 1999, 4, 597-609.

(10) Kroker, A. J.; Bruning, J. B. Review of the structural and dynamic mechanisms of PPAR $\gamma$ partial agonism. PPAR Res. 2015, 2015, 816856.

(11) Camp, H. S.; Li, O.; Wise, S. C.; Hong, Y. H.; Frankowski, C. L.; Shen, X.; Vanbogelen, R.; Leff, T. Differential activation of peroxisome proliferator-activated receptor-gamma by troglitazone and rosiglitazone. Diabetes 2000, 49, 539-547.

(12) Ahmadian, M.; Suh, J. M.; Hah, N.; Liddle, C.; Atkins, A. R.; Downes, M.; Evans, R. M. PPAR $\gamma$ signaling and metabolism: the good, the bad and the future. Nat. Med. 2013, 99, 557-566.

(13) van Marrewijk, L. M.; Polyak, S. W.; Hijnen, M.; Kuruvilla, D.; Chang, M. R.; Shin, Y.; Kamenecka, T. M.; Griffin, P. R.; Bruning, J. B. SR2067 reveals a unique kinetic and structural signature for PPAR $\gamma$ partial agonism. ACS Chem. Biol. 2016, 11, 273-283.

(14) Miao, F.; Yang, X.-J.; Zhou, L.; Hu, H.-J.; Zheng, F.; Ding, X.D.; Sun, D.-M.; Zhou, C.-D.; Sun, W. Structural modification of sanguinarine and chelerythrine and their antibacterial activity. Nat. Prod. Res. 2011, 25, 863-875.

(15) Niu, X.; Fan, T.; Li, W.; Xing, W.; Huang, H. The antiinflammatory effects of sanguinarine and its modulation of inflammatory mediators from peritoneal macrophages. Eur. J. Pharmacol. 2012, 689, 262-269.

(16) Gaziano, R.; Moroni, G.; Buè, C.; Miele, M. T.; SinibaldiVallebona, P.; Pica, F. Antitumor effects of the benzophenanthridine alkaloid sanguinarine: Evidence and perspectives. World J. Gastrointest. Oncol. 2016, 8, 30-39.

(17) Deroussent, A.; Ré, M.; Hoellinger, H.; Cresteil, T. Metabolism of sanguinarine in human and in rat: characterization of oxidative metabolites produced by human CYP1A1 and CYP1A2 and rat liver microsomes using liquid chromatography-tandem mass spectrometry. J. Pharm. Biomed. Anal. 2010, 52, 391-397.
(18) Chow, Y.-L.; Sato, F. Screening of isoquinoline alkaloids for potent lipid metabolism modulation with Caenorhabditis elegans. Biosci., Biotechnol., Biochem. 2013, 77, 2405-2412.

(19) Dagon, Y.; Avraham, Y.; Berry, E. M. AMPK activation regulates apoptosis, adipogenesis, and lipolysis by eIF $2 \alpha$ in adipocytes. Biochem. Biophys. Res. Commun. 2006, 340, 43-47.

(20) Daval, M.; Diot-Dupuy, F.; Bazin, R.; Hainault, I.; Viollet, B.; Vaulont, S.; Hajduch, E.; Ferré, P.; Foufelle, F. Anti-lipolytic action of AMP-activated protein kinase in rodent adipocytes. J. Biol. Chem. 2005, 280, 25250-25257.

(21) Poulos, S. P.; Dodson, M. V.; Hausman, G. J. Cell line models for differentiation: preadipocytes and adipocytes. Exp. Biol. Med. 2010, $235,1185-1193$.

(22) Kennedy, A.; Martinez, K.; Schmidt, S.; Mandrup, S.; LaPoint, K.; McIntosh, M. Antiobesity mechanisms of action of conjugated linoleic acid. J. Nutr. Biochem. 2010, 21, 171-179.

(23) Chow, Y.-L.; Sogame, M.; Sato, F. 13-Methylberberine, a berberine analogue with stronger anti-adipogenic effects on mouse 3T3-L1 cells. Sci. Rep. 2016, 6, 38129.

(24) Huang, C.; Zhang, Y.; Gong, Z.; Sheng, X.; Li, Z.; Zhang, W.; Qin, Y. Berberine inhibits 3T3-L1 adipocyte differentiation through the PPARy pathway. Biochem. Biophys. Res. Commun. 2006, 348, 571578 .

(25) Handschin, C.; Spiegelman, B. M. Peroxisome proliferatoractivated receptor $\gamma$ coactivator 1 coactivators, energy homeostasis, and metabolism. Endocr. Rev. 2006, 27, 728-735.

(26) Wilson-Fritch, L.; Nicoloro, S.; Chouinard, M.; Lazar, M. A.; Chui, P. C.; Leszyk, J.; Straubhaar, J.; Czech, M. P.; Corvera, S. Mitochondrial remodeling in adipose tissue associated with obesity and treatment with rosiglitazone. J. Clin. Invest. 2004, 114, 1281-1289.

(27) Willson, T. M.; Brown, P. J.; Sternbach, D. D.; Henke, B. R. The PPARs: from orphan receptors to drug discovery. J. Med. Chem. 2000, 43, 527-550.

(28) Hardie, D. G. AMPK: a key regulator of energy balance in the single cell and the whole organism. Int. J. Obes. 2008, 32, S7-S12.

(29) Daval, M.; Diot-Dupuy, F.; Bazin, R. Anti-lipolytic action of AMP-activated protein kinase in rodent adipocyte. J. Biol. Chem. 2005, 280, 25250-25257.

(30) Hardie, D. G. AMPK: a target for drugs and natural products with effects on both diabetes and cancer. Diabetes 2013, 62, 21642172.

(31) Choi, J. H.; Banks, A. S.; Kamenecka, T. M.; Busby, S. A.; Chalmers, M. J.; Kumar, N.; Kuruvilla, D. S.; Shin, Y.; He, Y.; Bruning, J. B.; Marciano, D. P.; Cameron, M. D.; Laznik, D.; Jurczak, M. J.; Schürer, S. C.; Vidović, D.; Shulman, G. I.; Spiegelman, B. M.; Griffin, P. R. Antidiabetic actions of a non-agonist PPAR $\gamma$ ligand blocking Cdk5-mediated phosphorylation. Nature 2011, 477, 477-481.

(32) Gregoire, F. M.; Zhang, F.; Clarke, H. J.; Gustafson, T. A.; Sears, D. D.; Favelyukis, S.; Lenhard, J.; Rentzeperis, D.; Clemens, L. E.; Mu, Y.; Lavan, B. E. MBX-102/JNJ39659100, a novel peroxisome proliferator activated receptor-ligand with weak transactivation activity retains antidiabetic properties in the absence of weight gain and edema. Mol. Endocrinol. 2009, 23, 975-988.

(33) Hara, K.; Boutin, P.; Mori, Y.; Tobe, K.; Dina, C.; Yasuda, K.; Yamauchi, T.; Otabe, S.; Okada, T.; Eto, K.; Kadowaki, H.; Hagura, R.; Akanuma, Y.; Yazaki, Y.; Nagai, R.; Taniyama, M.; Matsubara, K.; Yoda, M.; Nakano, Y.; Tomita, M.; Kimura, S.; Ito, C.; Froguel, P.; Kadowaki, T. Genetic variation in the gene encoding adiponectin is associated with an increased risk of type 2 diabetes in the Japanese population. Diabetes 2002, 51, 536-540.

(34) Yamauchi, T.; Kamon, J.; Waki, H.; Terauchi, Y.; Kubota, N.; Hara, K.; Mori, Y.; Ide, T.; Murakami, K.; Tsuboyama-Kasaoka, N.; Ezaki, O.; Akanuma, Y.; Gavrilova, O.; Vinson, C.; Reitman, M. L.; Kagechika, H.; Shudo, K.; Yoda, M.; Nakano, Y.; Tobe, K.; Nagai, R.; Kimura, S.; Tomita, M.; Froguel, P.; Kadowaki, T. The fat-derived hormone adiponectin reverses insulin resistance associated with both lipoatrophy and obesity. Nat. Med. 2001, 7, 941-946. 
(35) Chen, L.; Li, Q.-Y.; Shi, X.-J.; Mao, S.-L.; Du, Y.-L. 6Hydroxydaidzein enhances adipocyte differentiation and glucose uptake in 3T3-L1 cells. J. Agric. Food Chem. 2013, 61, 10714-10719.

(36) Chang, L.; Chiang, S. H.; Saltiel, A. R. Insulin signaling and the regulation of glucose transport. Mol. Med. 2004, 10, 65-71.

(37) Zhou, L.; Yang, Y.; Wang, X.; Liu, S.; Shang, W.; Yuan, G.; Li, F.; Tang, J.; Chen, M.; Chen, J. Berberine stimulates glucose transport through a mechanism distinct from insulin. Metabolism. 2007, 56, 405-412.

(38) Copeland, R. A.; Pompliano, D. L.; Meek, T. D. Drug-target residence time and its implications for lead optimization. Nat. Rev. Drug Discovery 2006, 5, 730-739.

(39) Adhami, V. M.; Aziz, M. H.; Mukhtar, H.; Ahmad, N. Activation of prodeath $\mathrm{Bcl}-2$ family proteins and mitochondrial apoptosis pathway by sanguinarine in immortalized human $\mathrm{HaCaT}$ keratinocytes. Clin. Cancer Res. 2003, 9, 3176-3182.

(40) Vavrecková, C.; Ulrichová, J.; Hajdúch, M.; Grambal, F.; Weigl, E.; Simánek, V. Effect of quaternary benzo[c]phenanthridine alkaloids sanguinarine, chelerythrine and fagaronine on some mammalian cells. Acta Univ. Palacki. Olomuc., Fac. Med. 1994, 138, 7-10.

(41) Vrba, J.; Doležel, P.; Vičar, J.; Ulrichová, J. Cytotoxic activity of sanguinarine and dihydrosanguinarine in human promyelocytic leukemia HL-60 cells. Toxicol. In Vitro 2009, 23, 580-588.

(42) Ansari, K. M.; Dhawan, A.; Khanna, S. K.; Das, M. In vivo DNA damaging potential of sanguinarine alkaloid, isolated from argemone oil, using alkaline Comet assay in mice. Food Chem. Toxicol. 2005, 43, 147-153.

(43) Vrublova, E.; Vostalova, J.; Vecera, R.; Klejdus, B.; Stejskal, D.; Kosina, P.; Zdarilova, A.; Svobodova, A.; Lichnovsky, V.; Anzenbacher, P.; Dvorak, Z.; Vicar, J.; Simanek, V.; Ulrichova, J. The toxicity and pharmacokinetics of dihydrosanguinarine in rat: a pilot study. Food Chem. Toxicol. 2008, 46, 2546-2553.

(44) Montanari, R.; Saccoccia, F.; Scotti, E.; Crestani, M.; Godio, C.; Gilardi, F.; Loiodice, F.; Fracchiolla, G.; Laghezza, A.; Tortorella, P.; Lavecchia, A.; Novellino, E.; Mazza, F.; Aschi, M.; Pochetti, G. Crystal structure of the peroxisome proliferator-activated receptor gamma (PPAR $\gamma$ ) ligand binding domain complexed with a novel partial agonist: a new region of the hydrophobic pocket could be exploited for drug design. J. Med. Chem. 2008, 24, 7768-7776.

(45) Guasch, L.; Sala, E.; Valls, C.; Blay, M.; Mulero, M.; Arola, L.; Pujadas, G.; Garcia-Vallvé, S. Structural insights for the design of new PPARgamma partial agonists with high binding affinity and low transactivation activity. J. Comput.-Aided Mol. Des. 2011, 8, 717-728.

(46) Hughes, T. S.; Giri, P. K.; de Vera, I. M. S.; Marciano, D. P.; Kuruvilla, D. S.; Shin, Y.; Blayo, A.-L.; Kamenecka, T. M.; Burris, T. P.; Griffin, P. R.; Kojetin, D. J. An alternate binding site for PPAR $\gamma$ ligands. Nat. Commun. 2014, 5, 3571.

(47) Psotová, J.; Klejdus, B.; Vecera, R.; Kosina, P.; Kubán, V.; Vicar, J.; Simánek, V.; Ulrichová, J. A liquid chromatographic-mass spectrometric evidence of dihydrosanguinarine as a first metabolite of sanguinarine transformation in rat. J. Chromatogr. B: Anal. Technol. Biomed. Life Sci. 2006, 830, 165-172.

(48) Sakaue, H.; Ogawa, W.; Matsumoto, M.; Kuroda, S.; Takata, M.; Sugimoto, T.; Spiegelman, B. M.; Kasuga, M. Posttranscriptional control of adipocyte differentiation through activation of phosphoinositide 3-kinase. J. Biol. Chem. 1998, 273, 28945-28952.

(49) Ohtera, A.; Miyamae, Y.; Nakai, N.; Kawachi, A.; Kawada, K.; Han, J.; Isoda, H.; Neffati, M.; Akita, T.; Maejima, K.; Masuda, S.; Kambe, T.; Mori, N.; Irie, K.; Nagao, M. Identification of 6octadecynoic acid from a methanol extract of Marrubium vulgare $\mathrm{L}$. as a peroxisome proliferator-activated receptor $\gamma$ agonist. Biochem. Biophys. Res. Commun. 2013, 440, 204-209.

(50) Saito, K.; Lee, S.; Shiuchi, T.; Toda, C.; Kamijo, M.; InagakiOhara, K.; Okamoto, S.; Minokoshi, Y. An enzymatic photometric assay for 2-deoxyglucose uptake in insulin-responsive tissues and 3T3L1 adipocytes. Anal. Biochem. 2011, 412, 9-17. 